\title{
EDUTECH
}

\section{PENGEMBANGAN E-MODUL BERBASIS WEB DENGAN MENGGUNAKAN APLIKASI MOODLE PADA MATA KULIAH PENGELOLAAN PER- PUSTAKAAN}

\section{Oleh :}

Eza Yayang, Eldarni

Email : eldarni_160161@yahoo.co.id

\begin{abstract}
Abstrack. Development e-modul web based of management library course was done as efforts learning resources supplementation for college student as a learning material that suitable with advisability media and material criteria. So that helps student of college to get course material suitable with syllabus till student of college can learn independently with easiness access whenever and wherever. The kind of research was done is research and development $(R \& D)$. The validity test of product was done to four persons as validator with two persons as material validator and two persons as media validator. The product test was done to the student of college with major curriculum and educational technology FIP UNP that attend management library course with 2016 yaer of entry as much as 38 follow pretest and posttest for testing the effectiveness e-modul web based with see the differentiation both of them. Based on the result of advisability assessment from media validator and material validator was gotten the result of material validation 1 with average as much as 3,9 was categorized good, from material validation 2 was gotten average as much as 4,35 was categogrized very good and then the result of media validation 1 was gotten average as much as 4,35 was categorized very good while media validation 2 was gotten average as much as 4,65 was categorized very good. The result of practicality was gotten tcount as much as 7,413 then was seen ttable used table $t$ with $d f=N-1=38-1=37$ with $\alpha 0,05$ so that ttable is 2,042. So that, tcount $>$ ttable therefore was found significant differentiation between the result of learn before and after has given e-modul web based. Based on the result of validation, practicality, and effectiveness can make conclution that e-modul web based that was developed valid, practice and effective using in learning process management library course.
\end{abstract}

Informasi Artikel :

Artikel diterima 29 November 2018

Perbaikan 28 Januari 2019

Diterbitkan 14 Februari 2019

Terbit Online 15 Febuari 2019

Kata kunci: e-modul, web, moodle, library management.

\section{A. PENDAhuluan}

Para ahli menyimpulkan abad 21 merupakan abad pengetahuan karena pengetahuan menjadi fondasi utama segala aspek kehidupan. Pendidikan di abad pengetahuan menuntut adanya pengelolaan pendidikan yang modern dan profesional dengan bernuansa akadeNo. SK Akreditasi Ristekdikti : 34/E/KPT/2018 mis dan edukatif. Sehingga perlunya pencerahan dan pemberdayaan dari setiap jenis dan jenjang pendidikan. Pencerahan dan pemberdayaan tersebut salah satunya dapat dilakukan dari aspek pengadaan sumber belajar, sumber belajar dapat diupayakan dengan melakukan pengembangan sumber belajar secara

DOI:https://doi.org/10.17509/e.v18i1.14113 
terus-menerus. Pengembangan sumber belajar dapat memanfaatkan perkembangan teknologi yang terjadi pada era globalisasi saat ini. Kemajuan teknologi menawarkan sumber daya pembelajaran yang melimpah untuk mengakses dengan mudah, lebih fleksibel dan dalam berbagai cara (Rahmi, Effendi, dan Ansyar, 2017). Sehingga dapat dipadukan antara pembelajaran dan teknologi, pembelajaran atau proses belajar mengajar dengan intensitas penggunaan jaringan informasi dan teknologi komunikasi disebut sebagai $E$ learning (Abdulhak, 2017).

Program studi Teknologi Pendidikan FIP UNP, pada umumnya menerapkan metode diskusi pada kegiatan perkuliahan dengan bentuk pola pembelajaran berupa interaksi antara mahasiswa dengan mahasiswa dan dosen dengan mahasiswa. Diskusi diawali dengan presentasi materi oleh kelompok mahasiswa. Setiap pertemuan, mahasiswa mempresentasikan materi yang berbeda oleh kelompok mahasiswa yang berbeda pula dengan berpedoman kepada silabus. Fungsi kelompok presentasi adalah sebagai pemateri yang menyampaikan hasil diskusi mereka terkait penemuan kumpulan materi dari berbagai sumber bahan belajaryang dikemas dalam bentuk makalah sebagai pertanggungjawaban kerja kelompok.

Meskipun masing-masing mahasiswa telah membekali diri dengan buku pegangan, namun buku pegangan tersebut tidak sepenuhnya mampu membantu mahasiswa kritis terhadap materi perkuliahan. Karena pada umumnya isi buku hanya menjelaskan materi berupa teks saja, hanya pada bagian tertentu penjelasan materi dilengkapi dengan ilustrasi. Sehingga tidak semua materi mampu divisualisasikan oleh mahasiswa, akibatnya terkadang mahasiswa memiliki penafsiran yang salah dalam memahami materi. Karena itu, mahasiswa membutuhkan suatu sumber belajar yang dapat dijadikan sebagai suplementasi untuk menunjang aktivitas perkuliahan. Karena mahasiswa tidak terlepas dari penggunaan peralatan teknologi dalam keseharian mereka, maka peran teknologi dapat dimanfaatkan dalam hal pengembangansumber belajar.

Jenis sumber belajar yang mampu memenuhi kriteria tersebut adalah modul. Prastowo (Lestari, 2013:6) mendefenisikan modul sebagai "bahan ajar yang ditulis dengan tujuan agar siswa dapat belajar secara mandiri tanpa atau dengan bimbingan guru, oleh karena itu, modul harus berisi tentang petunjuk belajar, kompetensi yang akan dicapai, isi materi pelajaran, informasi pendukung, 
latihan soal, petunjuk kerja, evaluasi dan balikan terhadap hasil evaluasi". Jika pengembangan dan penayangan modul dilakukan dengan memanfaatkan teknologi maka dapat dikatakan sebagai e-modul.

Salah satu aplikasi pengembangan emodul berbasis web yang dapat dimanfaatkan untuk mewujudkan elearning tersebut adalah Moodle. Moodle merupakan sebuah Course Open Source Management System (CMS), juga dikenal sebagai Sistem Manajemen Pembelajaran (LMS) atau Virtual Learning Enviroment (VLE). Ini telah menjadi populer di kalangan pendidik di seluruh dunia sebagai alat untuk membuat situs web online yang dinamis bagi siswa mereka. Peran e-modul dalam hal ini adalah sebagai topik perkuliahan yang akan didiskusikan oleh mahasiswa, dengan pemberian e-modulmereka mempelajari materi perkuliahan secara mandiri kemudian mereka diberikan kebebasan untuk mengemukakan pendapat mereka seputar apa yang mereka pelajari dari e-modul tersebut melalui diskusi online. Sehingga dengan adanya fasilitas yang seperti itu maka mahasiswa bebas mengeluarkan pendapat yang belum tersampaikandalam kegiatan diskusi secara langsung. Selain dari itu jika emodul ini diberikan secara berkala maka mahasiswa akan terbiasa dengan pemikiran yang kritis terkait dengan materi perkuliahan.

Purwanto juga mendefenisikan modul sebagai bahan belajar yang dirancang secara sistematis berdasarkan kurikulum tertentu dan dikemas dalam bentuk satuan pembelajaran terkecil dan memungkinkan dapat dipelajari secara mandiri dalam satuan waktu tertentu (Warsita, 2011:111). E-Modul merupakan sebuah bentuk penyajian bahan belajar mandiri yang disusun secara sistematis ke dalam unit pembelajaran tertentu, yang disajikan dalam format elektronik, dimana setiap kegiatan pembelajaran di dalamnya dihubungkan dengan tautan (link) sebagai navigasi yang membuat peserta didik menjadi lebih interaktif dengan program, dilengkapi dengan penyajian video tutorial, animasi dan audio untuk memperkaya pengalaman belajar (Ditjen Pendidikan Dasar dan Menengah, 2017:3).

Jenis penelitian yang digunakan dalam penelitian ini yaitu penelitian pengembangan atau dikenal dengan istilah Research and Development $(R \& D)$ yang dapat didefenisikan sebagai metode penelitian yang secara sengaja, sistematis, bertujuan/ diarahkan untuk mencaritemukan, merumuskan, merumuskan, memper- 
baiki, mengembangkan, menghasilkan, menguji keefektifan produk, model, metode/strategi/cara, jasa, prosedur tertentu yang lebih unggul, baru, efektif, efisien, produktif, dan bermakna (Putra, 2012:67). Penelitian ini menggunakan model pengembangan yang dikemukakan oleh Brog dan Gall dalam Emzir
(2015:271) yang mana mereka memaparkan langkah-langkah dalam penelitian dan pengembangan yang bersifat siklus. menyesuaikan dengan kebutuhan peneliti, peneliti membatasi langkah-langkah penelitian menjadi lima langkah-langkah penelitianyaitu sebagai berikut :

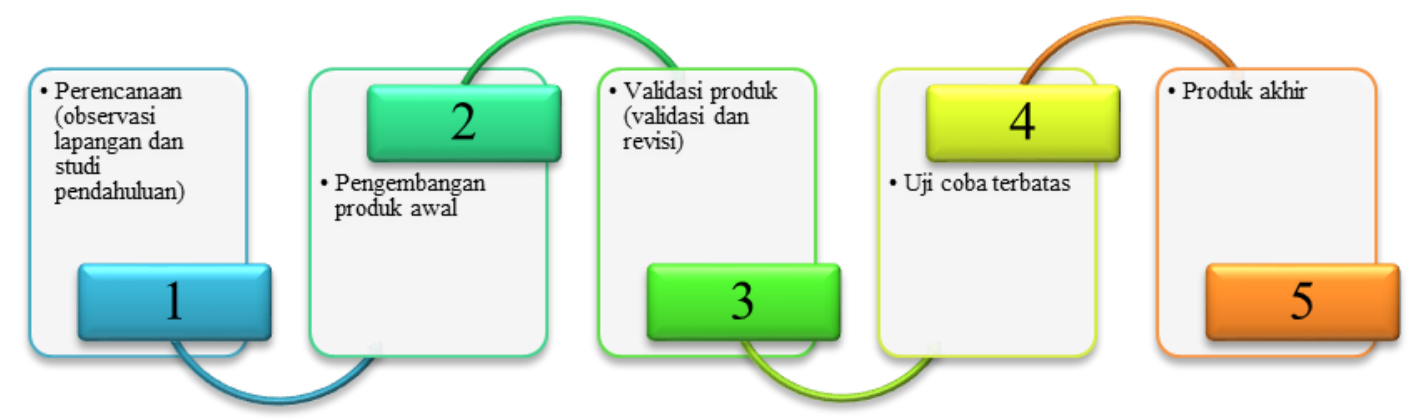

Grafik 1. langkah-langkah dalam penelitian dan pengembangan yang bersifat siklus

Pengembangan e-modul berbasis pengembangan dapat terlaksana dengan web menggunakan aplikasi moodle ini baik. Untuk lebih memperjelas alur prosmembutuhkan prosedur kerja yang es pengembangan produk dapat dilihat sistematis dan terarah. Sehingga proses pada gambar berikut:

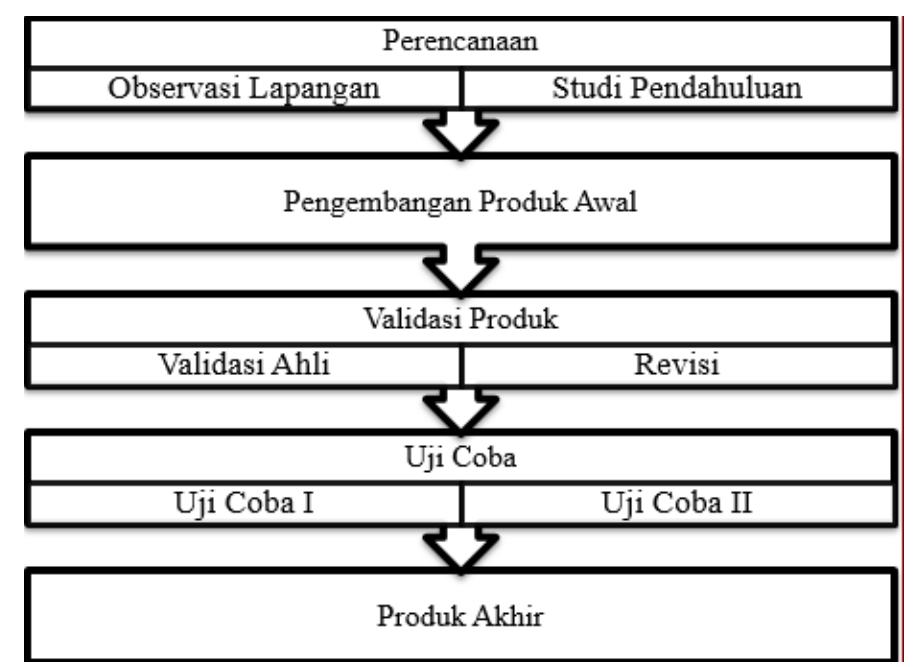

Gambar 1. Bagan Prosedur Pengembangan Modifikasi dari Model Pengembangan Menurut Brog \& Gall 
Instrumen pengumpulan data yang digunakan dalam penelitian ini yaitu : (1) angket, (2) dokumentasi, (3) format penilaian, (4) tes. Teknik analisis data yang dilakukan dalam penelitian yaitu analisis validitas, analisis praktikalitas dan analisis efektifitas.

\section{B. HASIL PENELITIAN}

Perencanaan dalam pembuatan media e-modul berbasis web dengan aplikasi moodle pada mata kuliah Pengelolaan Perpustakaan ini dilakukan dua tahap yaitu observasi lapangan dan studi pendahuluan. Pada tahap ini peneliti melakukan perumusan isi materi perkuliahan dan analisis instruksional untuk menelusuri dan menemukan kemungkinan-kemungkinan permasalahan yang muncul dalam proses perkuliahan.

1. Pengembangan Produk Awal

E-modul berbasis web merupakan sebuah bentuk penyajian bahan belajar mandiri yang disusun secara sistematis ke dalam unit pembelajaran terkecil untuk mencapai tujuan pembelajaran tertentu dalam bentuk format elektronik yang dapat diakses secara online. Miarso (2011 : 267) berpendapat bahwasanya "paling sedikit ada dua kemungkinan untuk melaksanakan prinsip belajar mandiri yaitu (1) digunakan program No. SK Akreditasi Ristekdikti : 34/E/KPT/2018 belajar yang mengandung petunjuk untuk belajar sendiri oleh peserta didik dengan bantuan guru yang minimal dan (2) melibatkan siswa dalam merencanakan dan melaksanakan kegiatan". Karena itu e-modul berbasis web dapat menjadi sarana diskusi meski tidak berada pada tempat yang sama. Beberapa hasil pengembangan produk awal emodul berbasis web meliputi :merangkum materi menjadi emodul, mengembangkan flowchart, pembelian domain dan hosting ke internet,

\section{Validasi Produk}

Kegiatan validasi produk ini melibatkan dua orang validator ahli materi yang juga merupakan dosen Jurusan Kurikulum dan Teknologi Pendidikan yaitu Ibu Dra. Fetri Yeni J, M.Pd dan Ibu Dr. Abna Hidayati,S.Pd,M.Pd. Kemudian juga melibatkan validator media yang juga merupakan dosen jurusan KTP yaitu Bapak Nofri Hendri,M.Pd dan Ibu Novrianti,M.Pd. Tugas validator yaitu memberikan penilaian terhadap produk melalui lembar penilaian kelayakan produk. Hasil perolehan penilaian validasi materi ditinjau dari kebenaran konsep, penyajian materi, instruksional, dan DOI:https://doi.org/10.17509/e.v18i1.14113 
evaluasi oleh validator materi 1 dan validator materi 2 .
Penilaian kelayakan materi dari tiap-tiap variabel dapat dilihat pada tabel berikut :

Tabel 1. Penilaian Kelayakan E-modul Berbasis Web pada Mata Kuliah Pengelolaan Perpustakaan oleh Ahli Materi 1

\begin{tabular}{clc}
\hline No & \multicolumn{1}{c}{ Kriteria Varibael } & Skor Tiap Variabel \\
\hline 1 & Kebenaran konsep & 3,9 \\
2 & Penyajian materi & 3,8 \\
3 & Instruksional & 4 \\
4 & Evaluasi & 4 \\
Rerata & & 3,9 \\
\hline
\end{tabular}

Secara keseluruhan, tingkat penilaian kriteria "baik atau valid". Penilaian kevalidasi dari validator materi 1 mem- layakan materi dari penilaian tiap-tiap peroleh skor rata-rata sebesar 3,9 dengan variabel dapat dilihat pada tabel berikut :

Tabel 2. Penilaian Kelayakan E-modul Berbasis Web pada Mata Kuliah Pengelolaan Perpustakaan oleh Ahli Materi 2

\begin{tabular}{clc}
\hline No & \multicolumn{1}{c}{ Kriteria Varibael } & Skor Tiap Variabel \\
\hline 1 & Kebenaran konsep & 4,2 \\
2 & Penyajian materi & 4,5 \\
3 & Instruksional & 4,3 \\
4 & Evaluasi & 4,3 \\
\multirow{2}{*}{ Rerata } & & 4,35 \\
\hline
\end{tabular}

Secara keseluruhan, tingkat penilaian validasi dari validator materi 2 memperoleh skor rata-rata sebesar 4,35 dengan kriteria " sangat baik atau sangat valid".

Validator media memberikan penilaian terhadap aspek-aspek media No. SK Akreditasi Ristekdikti : 34/E/KPT/2018 yang terdapat pada pengembangan produk melalui lembar penilaian validitas. Kegiatan validasi media ini dilakukan langsung berhadapan antara pengembang dengan validator, sehingga pengembang dapat menerima masukan dan saran dari validator untuk perbaikan selanjutnya. Hasil perolehan penilaian DOI:https://doi.org/10.17509/e.v18i1.14113 
media ditinjau dari segi tampilan, Hasil perolehan penilaian validator keterbacaan, kemudahan penggunaan, media 1 pada tabel berikut : tes/evaluasi.

Tabel 3. Penilaian Kelayakan E-Modul Berbasis Web pada Mata Kuliah Pengelolaan Perpustakaan oleh Ahli Media 1

\begin{tabular}{clc}
\hline No & \multicolumn{1}{c}{ Kriteria Varibael } & Skor Tiap Variabel \\
\hline 1 & Tampilan & 4,11 \\
2 & Keterbacaan & 4,75 \\
3 & Kemudahan Penggunaan & 4 \\
4 & Evaluasi / Tes & 4,75 \\
\multicolumn{2}{l}{ Rerata } & $\mathbf{4 , 3 5}$ \\
\hline
\end{tabular}

Secara keseluruhan, tingkat validasi diperoleh menunjukkan bahwa e-modul dari ahli media 1 memperoleh rerata berbasis web dapat digunakan setelah sebesar 4,35 dengan kriteria " sangat revisi ringan. Hasil perolehan penilaian baik atau sangat valid". Angka yang validator media 2 pada tabel berikut :

Tabel 4. Penilaian Kelayakan E-Modul Berbasis Web pada Mata Kuliah Pengelolaan Perpustakaan oleh Ahli Media 2

\begin{tabular}{clc}
\hline No & \multicolumn{1}{c}{ Kriteria Varibael } & Skor Tiap Variabel \\
\hline 1 & Tampilan & 4,4 \\
2 & Keterbacaan & 4,5 \\
3 & Kemudahan Penggunaan & 5 \\
4 & Evaluasi / Tes & 5 \\
Rerata & $\mathbf{4 , 6 5}$ \\
\hline
\end{tabular}

Secara keseluruhan, tingkat validasi dari ahli media 2 memperoleh rerata sebesar 4,65 dengan kriteria "baik atau valid". Angka yang diperoleh menunjukkan bahwa emodul berbasis web dapat digunakan setelah revisi ringan.

3. Revisi Produk

Berdasarkan hasil analisis data di atas dapat disimpulkan bahwa secara keseluruhan aspek materi dan media e-modul berbasis web sudah baik, namun pada aspek tertentu perlu dilakukan revisi agar e-modul berbasis web lebih layak 
digunakan. Revisi terhadap produk dilakukan berdasarkan kepada komentar atau saran yang diberikan oleh validator pada lembar validasi. Sehingga dihasilkan bentuk uraian revisi e-modul berbasis web sebagai berikut :

\section{Revisi pada Materi}

Revisi terhadap materi dilakukan setelah kegiatan validasi dengan ahli materi. Hasil revisi menyesuaikan dengan komentar atau saran yang ditulis oleh validator pada lembar validasi materi. Berikut merupakan beberapa bagian materi yang direvisikan : (a) Ilustrasi cocokkan dengan materi, (b) Penambahan tes essay, (c) Penambahan perintah penggunaan sumber belajar lain selain e-modul.

5. Revisi pada Media
Revisi terhadap media dilakukan setelah kegiatan validasi dengan ahli media. Berikut merupakan beberapa bagian media yang direvisikan : (a) Menambah header ke dalam moodle, (b) Membuat animasi, (c) Soal yang disebarkan kepada mahasiswa lengkapi dengan timer.

6. Hasil Uji Coba Terbatas

Setelah produk divalidasi oleh validator, maka selanjutnya produk diuji cobakan. Uji coba dilakukan kepada 38 responden yang merupakan mahasiswa jurusan KTP yang mana mereka yang tergabung dalam kelas e-learning yang dibentuk pada minggu sebelumnya karena mereka telah diperkenalkan dengan produk. Rekapitulasi hasil praktikalitas emodul berbasis web dapat dilihat pada tabel berikut :

Tabel 5. Hasil Penilaian Praktikalitas E-Modul Berbasis Web pada Mata Kuliah Pengelolaan Perpustakaan Mahasiswa Jurusan KTP FIP UNP

\begin{tabular}{clccc}
\hline No & Aspek yang dinilai & Item & Rata-rata & Keterangan \\
\hline 1 & $\begin{array}{l}\text { Kemudahan } \\
\text { Penggunaan }\end{array}$ & $1-5$ & 4,43 & Sangat Praktis \\
2 & Manfaat & $6-9$ & 4,55 & Sangat Praktis \\
3 & Tampilan & $10-13$ & 4,41 & Sangat Praktis \\
4 & Penyajian Materi & $14-16$ & 4,49 & Sangat Praktis \\
5 & Evaluasi & $17-18$ & 4,51 & Sangat Praktis \\
& & 18 & 4,47 & Sangat Praktis \\
\hline o. SK Akreditasi Ristekdikti : 34/E/KPT/2018 & DOI:https://doi.org/10.17509/e.v18i1.14113
\end{tabular}


Tingkat praktikalitas dari hasi uji coba pada mahasiswa memperoleh rerata sebesar 4,47 dengan kriteria "sangat praktis". Berdasarkan data praktikalitas mahasiswa jurusan KTP pada tabel 14, dapat diketahui bahwa dari aspek secara umum respon mahasiswa terhadap emodul berbasis web yang digunakan adalah positif dengan kriteria sangat praktis.

\section{Deskripsi Efektifitas}

Pengetahuan awal mahasiswa dapat diketahui dengan melakukan pretest yang dilakukan pada pertemuan pertama dengan responden mahasiswa jurusan KTP kelas tempat dilakukannya observasi pada tahap perencanaan dengan jumlah siswa sebanyak 38 orang. Setelah mahasiswa tersebut diberikan pretest, kemudian mereka diberikan e-modul berbasis web. Pemberian e-modul berbasis web ini dilakukan dengan cara memberikan mereka sebuah alamat situs, kemudian mereka login menggunakan NIM masing-masing. Setelah mereka berhasil masuk, maka mereka memulai mempelajari emodul dengan cara mendownload emodul tersebut.

Setelah dilakukan pretest dan posttes terhadap 38 mahasiswa, maka diperoleh hasil seperti pada tabel di bawah ini :

Tabel 6. Hasil pretest dan posttes

\begin{tabular}{cccccc}
\hline No & $\begin{array}{c}\text { Nilai Pre- } \\
\text { test }\end{array}$ & $\begin{array}{c}\text { Nilai Post- } \\
\text { test }\end{array}$ & $\mathbf{d}$ & $\begin{array}{c}\mathbf{( x )} \mathbf{d}=(\mathbf{d}- \\
\mathbf{M d})\end{array}$ & $\left.\mathbf{( x}^{2}\right) \mathbf{d}$ \\
\hline 1 & 72 & 74 & 2 & $-2,211$ & 4,889 \\
2 & 74 & 72 & -2 & $-6,211$ & 38,577 \\
3 & 70 & 74 & 4 & $-0,211$ & 0,045 \\
4 & 74 & 72 & -2 & $-6,211$ & 38,577 \\
5 & 74 & 80 & 6 & 1,789 & 3,201 \\
6 & 76 & 78 & 2 & $-2,211$ & 4,889 \\
7 & 70 & 74 & 4 & $-0,211$ & 0,045 \\
8 & 76 & 78 & 2 & $-2,211$ & 4,889 \\
9 & 70 & 72 & 2 & $-2,211$ & 4,889 \\
10 & 70 & 76 & 6 & 1,789 & 3,201 \\
11 & 74 & 78 & 4 & $-0,211$ & 0,045 \\
12 & 70 & 72 & 2 & $-2,211$ & 4,889 \\
13 & 70 & 76 & 6 & 1,789 & 3,201 \\
14 & 68 & 74 & 6 & 1,789 & 3,201 \\
15 & 68 & 70 & 2 & $-2,211$ & 4,889 \\
\hline No. SK Akreditasi Ristekdikti : $34 / \mathrm{E} / \mathrm{KPT} / 2018$ & & DOI:https://doi.org/10.17509/e.v18i1.14113
\end{tabular}




\begin{tabular}{cccccc}
16 & 70 & 84 & 14 & 9,789 & 95,825 \\
17 & 78 & 80 & 2 & $-2,211$ & 4,889 \\
18 & 78 & 82 & 4 & $-0,211$ & 0,045 \\
19 & 68 & 78 & 10 & 5,789 & 33,513 \\
20 & 70 & 80 & 10 & 5,789 & 33,513 \\
21 & 76 & 82 & 6 & 1,789 & 3,201 \\
22 & 78 & 84 & 6 & 1,789 & 3,201 \\
23 & 70 & 78 & 8 & 3,789 & 14,357 \\
24 & 72 & 80 & 8 & 3,789 & 14,357 \\
25 & 78 & 82 & 4 & $-0,211$ & 0,045 \\
26 & 70 & 78 & 8 & 3,789 & 14,357 \\
27 & 70 & 74 & 4 & $-0,211$ & 0,045 \\
28 & 74 & 76 & 2 & $-2,211$ & 4,889 \\
29 & 78 & 80 & 2 & $-2,211$ & 4,889 \\
30 & 70 & 78 & 8 & 3,789 & 14,357 \\
31 & 68 & 74 & 6 & 1,789 & 3,201 \\
32 & 76 & 80 & 4 & $-0,211$ & 0,045 \\
33 & 78 & 82 & 4 & $-0,211$ & 0,045 \\
34 & 78 & 84 & 6 & 1,789 & 3,201 \\
35 & 76 & 78 & 2 & $-2,211$ & 4,889 \\
36 & 78 & 76 & -2 & $-6,211$ & 38,577 \\
37 & 74 & 76 & 2 & $-2,211$ & 4,889 \\
38 & 64 & 62 & -2 & $-6,211$ & 38,577 \\
Jumlah & $\mathbf{2 7 6 8}$ & $\mathbf{2 9 2 8}$ & $\mathbf{1 6 0}$ & $\mathbf{- 0 , 0 2}$ & $\mathbf{4 5 4 , 3 1 6}$ \\
\hline & & & & & \\
\hline
\end{tabular}

Berdasarkan hasil perhitungan uji efektifitas didapat $t_{\text {hitung }}$ sebesar 7,413 kemudian dilihat $\mathrm{t}_{\text {tabel }}$ menggunakan tabel $\mathrm{t}$, dengan $\mathrm{df}=\mathrm{N}-1=38-1=37$ dengan $\alpha$ 0,05 maka $t_{\text {tabel }}$ adalah 2,042. Jadi $t_{\text {hitung }}>$ $\mathrm{t}_{\text {tabel}}$, dengan demikian terdapat perbedaan yang signifikan terhadap hasil pretest dan posttest. Maka dapat disimpulkan bahwa e-modul berbasis web berpengaruh terhadap hasil belajar pada mata kuliah pengelolaan perpustakaan.

Hasil akhir validasi dan praktikalitas e-modul berbasis web yang dikemNo. SK Akreditasi Ristekdikti : 34/E/KPT/2018 bangkan berada pada kategori sangat baik sehingga dinyatakan layak untuk digunakan. Penilaian untuk e-modul berbasis web dapat dilihat pada tabell di bawah ini : 
Tabel 7. Penilaian Produk E-modul Berbasis Web Menggunakan Aplikasi

Moodle

\begin{tabular}{|c|c|c|c|c|c|c|c|}
\hline \multicolumn{6}{|c|}{ Validitas } & \multicolumn{2}{|c|}{ Praktikalitas } \\
\hline & \multicolumn{2}{|c|}{ Materi } & \multicolumn{3}{|c|}{ Media } & & \\
\hline \multicolumn{2}{|c|}{ Nilai } & Kategori & & lai & Kategori & Nilai & Kategori \\
\hline $\begin{array}{c}1 \\
3,9\end{array}$ & $\begin{array}{c}2 \\
4,35\end{array}$ & $\begin{array}{c}\text { Sangat val- } \\
\text { id }\end{array}$ & $\begin{array}{l}1 \\
4,3 \\
5\end{array}$ & $\begin{array}{c}2 \\
4,65\end{array}$ & Sangat valid & 4,47 & $\begin{array}{c}\text { Sangat prak- } \\
\text { tis }\end{array}$ \\
\hline
\end{tabular}

E-modul berbasis web yang telah dikembangkan memperoleh hasil validitas dari materi 1 jumlah rata-rata sebesar 3,9 dikategorikan baik atau valid sedangkan dari materi 2 memperoleh ratarata sebesar 4,35 dikategorikan sangat baik atau sangat valid dan hasil validitas dari media 1 memperoleh jumlah ratarata sebesar 4,35 dikategorikan sangat baik atau sangat valid sedangkan validitas dari media 2 memperoleh rata-rata sebesar 4,65 dikategorikan sangat baik atau sangat valid. Hasil uji praktikalitas memperoleh rata-rata sebesar 4,47 dikategorikan sangat praktis.

Hasil uji efektifitas diperoleh $t_{\text {hitung }}$ sebesar 7,413 kemudian dilihat $t_{\text {tabel }}$ menggunakan tabel t pada lampiran 15 dengan $\mathrm{df}=\mathrm{N}-1=38-1=37$ dengan $\alpha$ 0,05 maka $t_{\text {tabel }}$ adalah 2,042. Jadi $t_{\text {hitung }}>$ $t_{\text {tabel}}$, dengan demikian terdapat perbedaan yang signifikan antara hasil belajar sebelum dan setelah diberikan e-modul berbasis web.

Dari data uji coba produk yang telah dilakukan, maka e-modul berbasis web No. SK Akreditasi Ristekdikti : 34/E/KPT/2018 dinyatakan layak dijadikan sebagai sumber belajar tambahan mahasiswa yang dapat membantu mahasiswa mempelajari materi perkuliahan secara mandiri, dapat diakses kapan saja dan di mana saja sehingga mampu memberikan mahasiswa motivasi dalam belajar dan mengoptimalkan belajar mahasiswa dalam upaya mempelajari materi perkuliahan.

\section{SIMPULAN}

Berdasarkan analisis data yang telah diuraikan di atas, maka ditarik kesimpulan sebagai berikut : (1) Pengembangan e-modul berbasis web pada mata kuliah Pengelolaan Perpustakaan untuk mahasiswa jurusan Kurikulum dan Teknologi Pendidikan FIP UNP telah selesai dilakukan. Produk e-modul berbasis web ini dapat digunakan sebagai sumber belajar tambahan untuk mengoptimalkan belajar mahasiswa dalam mempelajari materi perkuliahan, (2) Hasil validitas dari materi 1 memperoleh jumlah rata-rata sebesar 3,9 dikategorikan baik atau valid sedangkan dari materi 2 memperoleh rata-rata sebesar 4,35 DOI:https://doi.org/10.17509/e.v18i1.14113 
dikategorikan sangat baik atau sangat valid dan hasil validitas dari media 1 memperoleh jumlah rata-rata sebesar 4,35 dikategorikan sangat baik atau sangat valid sedangkan validitas dari media 2 memperoleh rata-rata sebesar 4,65 dikategorikan sangat baik atau sangat valid, (3) Hasil uji praktikalitas memperoleh rata-rata sebesar 4,47 dikategorikan sangat praktis. Hasil uji efektifitas diperoleh $t_{\text {hitung }}$ sebesar 7,413 kemudian dilihat $\mathrm{t}_{\text {tabel }}$ menggunakan tabel $\mathrm{t}$ pada lampiran 15 dengan $\mathrm{df}=\mathrm{N}-1=38-1=37$ dengan $\alpha 0,05$ maka $t_{\text {tabel }}$ adalah 2,042. Jadi $t_{\text {hitung }}>t_{\text {tabel }}$, dengan demikian terdapat perbedaan yang signifikan antara hasil belajar sebelum dan setelah diberikan e-modul berbasis web.

\section{DAFTAR RUJUKAN}

Abudlhak,Ishak. (2017). E-Learning konsep dan implementasi. Bandung: UPI Press.

Ditjen Pendidikan Dasar dan Menengah, Direktorat Pembinaan SMA. (2017). Panduan Praktis Penyusu$\begin{array}{lll}\text { nan } & \text { E-Modul. } & \text { Diambil } \\ \text { dari } & & \text { https:// }\end{array}$ awan965.files.wordpress.com/2017 /09/panduan_penyusunan-e-modul2017 final_edit.pdf.

Emzir. (2015). Metodologi Penelitian Pendidikan: Kuantitatif dan Kualitatif. Jakarta : Rajawali Pers.
Lestari, Ika. (2013). Pengembangan Bahan Ajar Berbasis Kompetensi. Padang : Akademia Permata

Miarso, Yusufhadi. (2011). Menyemai Benih Teknologi Pendidikan. Jakarta: Kencana.

Putra, Nusa. (2011). Research \& Development (Penelitian dan Pengembangan : Suatu Pegantar). Jakarta : Rajawali Pers.

Rahmi, U., Effendi, Z. M., \& Ansyar, M. (2017). The Development of Message-Design Model in Blended Learning. The Asian Journal of Technology Management, 10(1), 1.

Riduwan. 2010. Skala Pengukuran Variabel-variabel Penelitian. Bandung : Alfabeta.

Warsita, Bambang. 2011. Pendidikan Jarak Jauh. Bandung : PT Remaja Rosdakarya. 